\title{
Composition of leucocytes in peripheral blood of Patagonian toothfish (Dissostichus eleginoides, Smitt, 1898) (Nototheniidae)
}

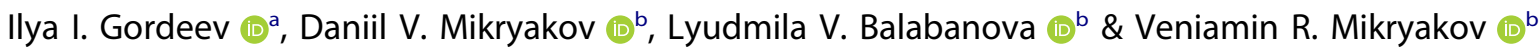 \\ aLaboratory of Pacific Salmons, Russian Federal Research Institute of Fisheries and Oceanography, Moscow, Russia; bl.D. Papanin \\ Institute for Biology of Inland Waters, Russian Academy of Sciences, Yaroslavl Region, Russia
}

\section{ABSTRACT}

The composition of leukocytes in the Patagonian toothfish (Dissostichus eleginoides Smitt, 1898), caught in the Scotia Sea at a depth of more than $1000 \mathrm{~m}$, was studied. Cells with various morphofunctional characteristics and cell structure were found. Lymphocytes were predominant, followed by, in decreasing order, eosinophils, monocytes, blast forms and neutrophils. The composition of leukocytes in the Patagonian toothfish consists of the same types of leukocytes as the earlier studied Antarctic toothfish (Dissostichus mawsoni Norman, 1937), but the percentage of white blood cells in the leukocyte formula differs between the two species.

\section{KEYWORDS}

Patagonian toothfish; blood: Nototheniidae; leukocytes

\section{Introduction}

Leukocytes are polymorphic and polyfunctional blood cells that perform a several physiological and immunological functions. They are involved in defending the body from foreign substances and they ensure fish adaptation to biotic and abiotic factors and immunity to parasites (Mikrjakov \& Balabanova 1979; Mikrjakov 1991; Secombes 1996; Galaktionov 2005; Van Muiswinkel \& VervoornVan Der Wal 2006). The main types of white blood cells in fishes are lymphocytes, monocytes, neutrophils, eosinophils and basophils (Ellis 1977; Ivanova 1983; Parish et al. 1986; Točilina 1994; Gruško et al. 2009). The composition of leukocytes reflects the specific and ecological features of fish and the ratio of some cell types reflects the functional state of the organism, as well as the pattern of the effect of biotic and abiotic factors (Ellis 1977; Parish et al. 1986; Točilina 1994; Mikrjakov et al. 2001).

The composition of leukocytes in fish has been most comprehensively studied in representatives of common and widely distributed species inhabiting freshwater, brackish and marine environments, and especially in fishing and aquaculture species (Ellis 1977; Barber et al. 1981; Ivanova 1983; Točilina 1994; Scapigliati et al. 2006; Voytsytskiy et al. 2008; Gruško et al. 2009; Gordeev et al. 2014; Izergina et al. 2014; Fazio et al. 2015). Data on leukocyte composition of fishes that are able to inhabit depths over 500-1500 m, perform vertical migrations and overcome strong hydrostatic and hydrodynamic resistance are quite scarce. The authors of this paper had previously studied the composition of leukocytes in the peripheral blood of the only congener of Dissostichus eleginoides the Antarctic toothfish (D. mawsoni Norman, 1937), which inhabits Antarctic and Subantarctic waters - and found resemblance with the white blood of most marine fishes (Gordeev et al. 2014). Other than basophils, the blood of D. mawsoni contains the same type of leukocytes as are found in freshwater species of bony fishes (Ivanova 1983).

Patagonian toothfish (D. eleginoides) (Perciformes: Notothoniidea) mostly inhabit the Subantarctic and northern areas of the Antarctic, but are also found in the southern and south-eastern areas of the South American shelf and continental slope. The Patagonian toothfish inhabits depths of up to $2000 \mathrm{~m}$ and is an important target species of commercial fisheries (Gon \& Heemstra 1990). Scapigliati et al. (2006) found lymphocytes, granulocytes, monocytes, erythrocytes and platelets in the tissues of the head kidney, spleen and intestinal mucosa using flow cytometry, but the leukocyte formula of the Patagonian toothfish has not been known. Among nototheniids there are also data on morphology of lymphomyeloid head kidney of Trematomus bernacchii (Boulenger, 1902) (Romano et al. 2002), Trematomus nicolai (Boulenger, 1902) and Chionodraco hamatus (Lönnberg, 1905) (Romano et al. 2000). Haematological parameters are already in use to provide information about the health status of fish and the quality of the water in which they live (Fazio et al. 2012; Fazio et al. 2013). 


\section{Material and methods}

Fish were caught in March 2013 from the Russian vessel Yantar-35 in the Scotia Sea (Atlantic sector; 53 $22^{\prime} 5$ S; $50^{\circ} 25^{\prime} 2 \mathrm{~W}$ ) at a depth of 1280-1340 m using bottom longlines (Mustad Autoline). Blood was collected from the tail vein straight after the catch. Seven donor fishes were immature, not wounded, with a mean weight of $10.45 \pm 2.43 \mathrm{~kg}$ and a mean length of $95.86 \pm 8.34 \mathrm{~cm}$. Dissection revealed an insignificant number of parasites. A blood drop (without anticoagulants) was put on a degreased glass slide and was smeared out, dried and fixed in $96 \%$ ethanol for 30 minutes. Dried-up slides were Romanovsky-Giemsa stained. Smears were studied using Biomed-6PR1-FK (x360) light microscope. Two hundred white blood cells were analysed on each of the smears and the percentages of lymphocytes, neutrophils, eosinophils, monocytes and blast forms were calculated. Fine photographs of cells were captured using a Keyence VHX-1000 digital microscope. Statistical data processing was performed using standard methods (Lakin 1980).

\section{Results}

The main cell types in the white blood of Patagonian toothfish and their percentages are given in Table 1.

Table 1. Blood cells of Patagonian toothfish.

\begin{tabular}{lc}
\hline Cell type & Percentage \\
\hline Lymphocytes & $91.6 \pm 1.63 \%$ \\
Eosinophils & $3.2 \pm 1.24 \%$ \\
Monocytes & $2.6 \pm 0.5 \%$ \\
Blast forms & $1.6 \pm 0.4 \%$ \\
Neutrophils & $1.0 \pm 0.0 \%$ \\
\hline
\end{tabular}

Morphological investigation demonstrated that the leukocytes of $D$. eleginoides are the same as in other fish species (Ivanova 1983; Golovina \& Trombickij 1989). The lymphocytes were small $(\varnothing 6.1 \times 5.3 \mu \mathrm{m})$, rounded nuclei filled most of the cell, and the cytoplasm was only a thin peripheral ring (Fig. 1a). Monocytes were relatively large cells $(\varnothing 13.1 \times 11.7 \mu \mathrm{m})$ with eccentric, oval or bean-shaped nuclei. Cytoplasm filled most of the cells (Fig. 1b). Neutrophils $(\varnothing 12.2 \times 11.5 \mu \mathrm{m})$ were characterized by eccentric, extended or segmented nuclei. Cytoplasm contained small vesicles (Fig. 1c). Eosinophils $(\varnothing 12.8 \times 10.9 \mu \mathrm{m})$ had eccentric rounded nuclei and visible large vesicles in the cytoplasm (Fig. 1a). Blast forms were large cells $(\varnothing 11.8 \times 10.0 \mu \mathrm{m})$ filled mostly by rounded nuclei and the remaining part comprising a thin layer of cytoplasm (Fig. 1d).

\section{Discussion}

The white blood of the Patagonian toothfish is formed mainly by lymphocytes, which - of all white blood cells - play the primary part in the immune system of vertebrate animals (Cooper 1980; Roitt et al. 2000; Galaktionov 2005; Haitov et al. 2012). Differing by functions, content of the membrane immunoglobulin receptors, duration of life and histogenesis, lymphocytes are heterogeneous and are divided into two main subpopulations: T-lymphocytes and B-lymphocytes (Mikrjakov 1991; Roitt et al. 2000; Van Muiswinkel \& Vervoorn-Van Der Wal 2006). T-lymphocytes fulfil the functions of foreign body recognition, antigen destruction, formation of specific immunity and

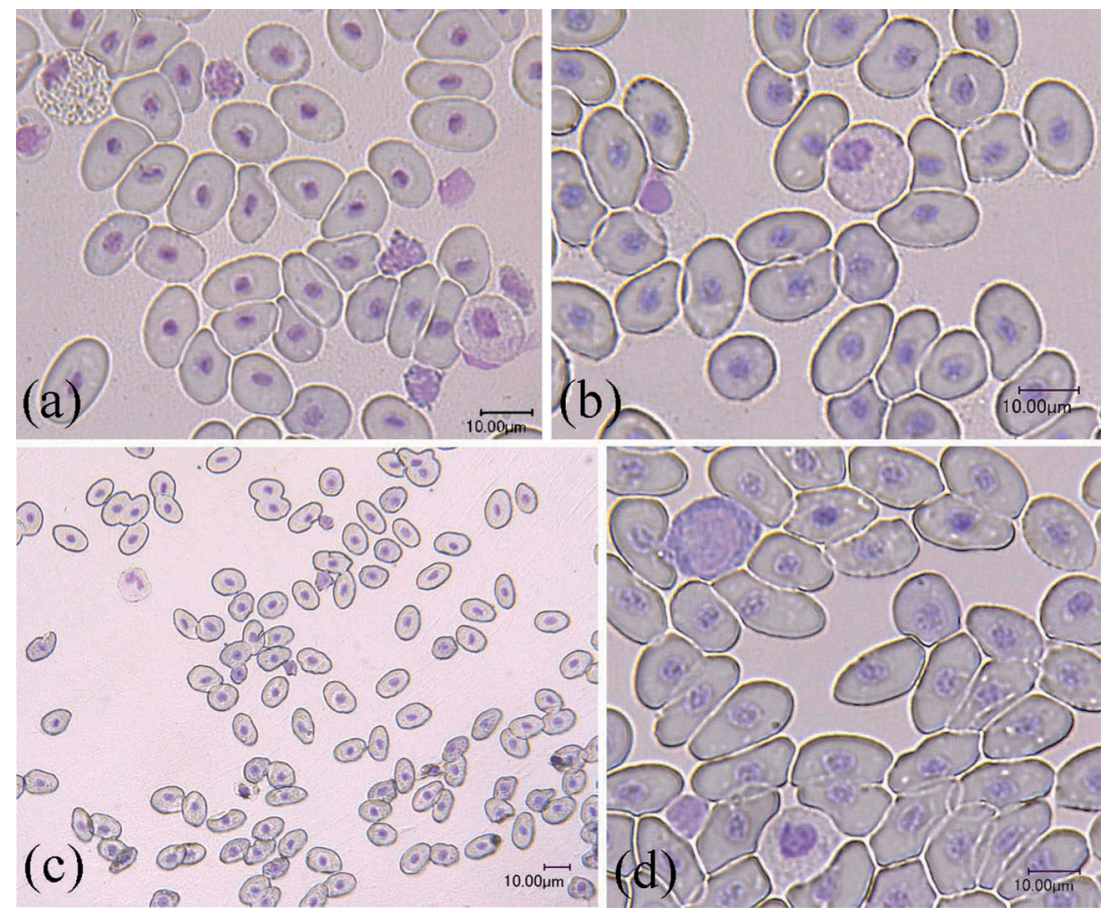

Figure 1. Blood cells of Patagonian toothfish (Dissostichus eleginoides): (a) lymphocyte (L), eosinophil (E); (b) monocyte (M); (c) neutrophil (N), (d) blast cell (B). Scale: $10 \mu \mathrm{m}$. 
adaptation of fishes to parasites and toxic agents. Populations of B-lymphocytes fulfil the functions of antibody synthesis, formation of precursors of antibody-forming cells and formation of memory cells (Mikrjakov 1991; Mikrjakov et al. 2001).

The same is true in most of the Perciformes (Balabanova 2002). Two types of granulocytes - neutrophils and eosinophils - were found among white blood cells of $D$. eleginoides. Relative content of these cells are small. They participate in microbe phagocytosis of microorganisms, synthesis of mediators of the immune response and nonspecific factors of immunity (Manning \& Nakanishi 1996; Galaktionov 2005; Havixbeck \& Barreda 2015; Katzenback 2015). There were also insignificant portions of immature blast forms. Their percentage in blood of freshwater fish species could be up to $10 \%$ (Ivanova 1983). However, it should be noted that quantitative characteristics of leukocytes of all previously studied freshwater and marine fishes, in one way or another, depend on the season, habitat, feeding and other factors (Ivanova 1983; Golovina \& Trombickij 1989; Točilina 1994; Mikrjakov et al. 2001).

Compared to D. eleginoides, D. mawsoni has a lower percentage of lymphocytes and a higher percentage of eosinophils and neutrophils (Gordeev et al. 2014). Leukocytes of the Patagonian toothfish differ from the ones of the Antarctic toothfish by size. The same size ranges for lymphocytes and granulocytes were found using a flow cytometric method for two other nototheniid species: Notothenia coriiceps and Trematomus hansoni (Scapigliati et al. 2006).

The results of the study demonstrate that leucocytes in the peripheral blood of the Antarctic toothfish are morpho-functionally and structurally heterogeneous: lymphocytes, monocytes, neutrophils, eosinophils and blast cells. The analysis of relative content of cell pools in the leukogram has shown that white blood of the toothfish is of lymphoid character. Dissostichus eleginoides differs from $D$. mawsoni by having a higher content of lymphocytes and a lower content of eosinophils and neutrophils. Taking into account the number of studied fish, these results are preliminary and this issue needs further study.

\section{Acknowledgements}

The authors wish to thank Dr Alexei M. Orlov for editing and the crew of the FV Yantar-35 (Orion Co., Ltd, Khabarovsk) for their help on collecting material and transporting it from the Antarctica.

\section{Disclosure statement}

No potential conflict of interest was reported by the authors.

\section{Funding}

The work was supported by the Russian Foundation for Basic Research grant no. 15-04-02645.

\section{ORCID}

Ilya I. Gordeev (D) http://orcid.org/0000-0002-6650-9120

Daniil V. Mikryakov (D) http://orcid.org/0000-0001-90861688

Lyudmila V. Balabanova (D) http://orcid.org/0000-00016931-3409

Veniamin R. Mikryakov (D) http://orcid.org/0000-00019052-223X

\section{References}

Balabanova L.V. 2002. Ul trastruktura granulocitov nekotoryh vidov okuneobraznyh ryb. (Fine structure of granulocytes of some Perciformes.) Biologiya Vnutrennih Vod1, 79-84.

Barber D.L., Westermann J.E. \& White M.G. 1981. The blood cells of the Antarctic icefish Chaenocephalus aceratus Zönnberg: light and electron microscopic observations. Journal of Fish Biology 19, 11-28.

Cooper E. 1980. Sravnitelnaya immunologiya. (Comparative immunology.) Moscow: Mir.

Ellis A.E. 1977. The leucocytes of fish: a review. Journal of Fish Biology 11, 453-491.

Fazio F., Faggio C., Marafioti S., Torre A., Sanfilippo M. \& Piccione G. 2012. Comparative study of haematological profile on Gobius niger in two different habitat sites: Faro Lake and Tyrrhenian Sea. Cahiers de Biologie Marine 53, 213-219.

Fazio F., Marafioti S., Torre A., Sanfilippo M., Panzera M. \& Faggio C. 2013. Haematological and serum protein profiles of Mugil cephalus: effect of two different habitats. Ichthyological Research 60, 36-42.

Fazio F., Piccione G., Arfuso F. \& Faggio C. 2015. Peripheral blood and head kidney haematopoietic tissue response to experimental blood loss in mullet (Mugil cephalus). Marine Biology Research 11, 197-202.

Galaktionov V.G. 2005. Evolucionnaja immunologija: učebnoe posobie. (Evolutionary immunology: textbook.) Moscow: IKC Akademkniga.

Golovina N.A. \& Trombickij I.D. 1989. Gematologija prudovyh ryb. (Hematology of pond fishes.) Kishinev: Shtiintsa.

Gon O. \& Heemstra P.C. (eds.) 1990. Fishes of the Southern Ocean. Grahamstown: J.L.B. Smith Institute of Ichthyology.

Gordeev I.I., Mikryakov D.V., Balabanova L.V. \& Mikryakov V.R. 2014. Composition of leucocytes in peripheral blood of Antarctic toothfish Dissostichus mawsoni (Nototheniidae). Journal of Ichthyology 54, 422-425.

Gruško M.P., Ložničenko O.V. \& Fedorova N.N. 2009. Gemopoezz u osetrovyh ryb. (Hemogenesis of sturgeons.) Astrakhan: Triada.

Haitov R.M., Ignat'Eva R.M. \& Sidorovič I.G. 2002. Immunologija. (Immunology.) Moscow: Medicina.

Havixbeck J.J. \& Barreda D.R. 2015. Neutrophil development, migration, and function in teleost fish. Biology 4, 715-734.

Ivanova N.T. 1983. Atlas kletok krovi ryb. (Atlas of fish blood cells.) Moscow: Legkaja i Piščevaja Promyšlennost. 
Izergina E.E., Izergin I.L. \& Izergina L.I. 2014. Atlas kletok krovi lososevyh ryb materikovogo pobereg'ja severnoj časti Ohotskogo morja. (Atlas of blood cells of salmons from continental coast of the northern part of Okhotsk Sea.) Magadan: Kordis.

Katzenback B.A. 2015. Antimicrobial peptides as mediators of innate immunity in teleosts. Biology 4, 607-639.

Lakin G. F. 1980. Biometrija. (Biometrics.) Moscow: Vysšaja Škola.

Manning M.J. \& Nakanishi T. 1996. The specific immune system: cellular defenses. In G. Iwata \& T. Nakanishi (eds.): The fish immune system: organism, pathogen and environment. Pp. 160-206. London: Academic Press.

Mikrjakov V.R. 1991. Zakonomernosti formirovanij a priobretennogo immuniteta $u$ ryb. (Trends of fishes acquired immunity development.) Rybinsk: Institute for the Biology of Inland Waters.

Mikrjakov V.R. \& Balabanova L.V. 1979. Kletočnye osnovy immuniteta u ryb. (Cellular bases of fish immunity.) In $\mathrm{N}$. V. Butorin \& V. A. Flerov (eds.): Fiziologija i parazitologija presnovodnyh žyvotnyh. (Physiology and parasitology of freshwater animals.) Pp. 57-64. Leningrad: Nauka.

Mikrjakov V.R., Balabanova L.V., Zabotkina E.A., Lapirova T.B., Popov A.V. \& Silkina N.I. 2001. Reakcija immunnoj systemy ryb na zagrjaznenie vody toksikantami i zakislenie sredy. (Reaction of fishes' immune system to water acidification and pollution by toxicants.) Moscow: Nauka.

Parish N., Wrathmell A., Hart S. \& Harris J. 1986. The leucocytes of the elasmobranch Scyliorhinus vanicula L.A morphological study. Journal of Fish Biology 28, 545-561.
Roitt M., Brostoff J. \& Male D.K. (eds.) 2000. Immunology. 5th edn. London: Mosby.

Romano N., Ceccariglia S., Abelli L., Mazzini M. \& Mastrolia L. 2000. Lymphomyeloid organs of the Antarctic fish Trematomus nicolai and Chionodraco hamatus (Teleostei: Notothenioidea): a comparative histological study. Polar Biology 23, 321-328.

Romano N., Ceccariglia S., Mastrolia L. \& Mazzini M. 2002. Cytology of lymphomyeloid head kidney of Antarctic fishes Trematomus bernacchii (Nototheniidae) and Chionodraco hamatus (Channicthyidae). Tissue Cell 34, 63-72.

Scapigliati G., Fochetti R., Tiberi M. \& Mazzini M. 2006. Morphological and flow cytometric characterization of leukocytes from the notothenioid teleosts Dissostichus eleginoides, Notothenia coriiceps, and Trematomus hansoni. Polar Biology 29, 872-877.

Secombes C.J. 1996. The nonspecific immune system: cellular defense. In G. Iwama \& T. Nakanishi (eds.): The fish immune system: organism, pathogen and environment. Pp. 63-105. London: Academic Press.

Točilina L.V. 1994. Lejkocitarnaja formula morskih ryb. (Leukocyte formula of marine fishes.) Hydrobiological Journal 30, 50-57.

Van Muiswinkel W.B. \& Vervoorn-Van Der Wal B. 2006. The immune system of fish. In P.T.K. Woo (ed.): Fish diseases and disorders. Vol. 1. Pp. 678-701. Wallingford: CABI.

Voytsytskiy V.M., Rodionova N.K., Khyzhniak S.V. \& Manylo L.G. 2008. Hematological characteristics of the Antarctic fish. Hydrobiological Journal 44, 66-74. 